Available online on 15.01.2021 at http://jddtonline.info
(C) 2011-21, publisher and licensee JDDT, This is an Open Access article which permits
unrestricted non-commercial use(CC By-NC), provided the original work is properly cited

Open Access Full Text Article

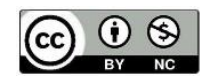

Review Article

\title{
Unani Medicine: Significance of Asbab-e-Sitta Zarooriya in times of Pandemic COVID-19
}

\author{
*1aAraf Fatma, 1bAisha Perveen, ${ }^{2}$ Sana Ur Rehman, ${ }^{3}$ Rabia Khan \\ 1a, 2 PG Scholar, ${ }^{1 b}$ Assistant Professor, Department of Tahaffuzi-wa-Samaji Tibb, School of Unani Medical Education and Research, Jamia Hamdard, \\ New Delhi, India
}

${ }^{3}$ PG Scholar, Department of Moalijat, School of Unani Medical Education and Research, Jamia Hamdard, New Delhi, India

\section{Article Info:}

Article History:

Received 11 Oct 2020;

Review Completed 08 Dec 2020

Accepted 19 Dec 2020;

Available online 15 Jan 2021

\section{Cite this article as:}

Fatma A, Perveen A, Rehman SU, Khan R, Unani Medicine: Significance of Asbab-e-Sitta Zarooriya in times of Pandemic COVID-19, Journal of Drug Delivery and Therapeutics. 2021; 11(1):156-161.

DOI: http://dx.doi.org/10.22270/jddt.v11i1.4636

*Address for Correspondence:

Araf Fatma, PG Scholar, Department of Tahaffuzi-waSamaji Tibb, School of Unani Medical Education and Research, Jamia Hamdard, New Delhi, India

\author{
Abstract
}

SARS COV-2 belongs to the beta coronavirus genera, it is believed that bats as warm-blooded flying vertebrates are ideal hosts for coronavirus gene source. COVID-19 caused by novel coronavirus was originated from Wuhan city of Hubei Province in China in December 2019. The common symptoms comprise fever, cough, malaise, and shortness of breath. The incubation period is between $2-14$ days. In this paper we have deliberated the structure of viruses; varying symptoms among COVID-19, SARS, MERS, and approach to tackling this problem with utmost effective Unani alternatives. Unani medicine endeavors to find the best conceivable ways by which a person can lead a hale and hearty life with minimum or zero sicknesses. Unani scholars believe by practicing important things like the use of fresh and clean water, breathing clean air and eating fresh food, upholding a balance between the mind and the body so that the metabolic processes can function effortlessly and the body wastes are evacuated, by enhancing immunity, and keeping an equilibrium between (Asbab-e-Sitta Zarooriya) six essential factors for life one can stay away from diseases.

Keywords: COVID-19, Unani Medicine, SARS COV-2, Asbab-e-Sitta Zarooriya.

\section{Introduction}

Coronavirus (COV) is a big family of viruses that are responsible to cause serious respiratory diseases. Coronavirus disease 2019 caused by SARS-CoV-2 is abbreviated as COVID-19 [CO: corona, VI: virus, D: disease, and 19: 2019 year]. The outburst of this illness was recognized as a Public Health Emergency of Global Concern on 30 January 2020 . With over $68,165,877$ cases and $1,557,385$ deaths reported to date (December, $10^{\text {th }}, 2020$ ), the COVID-19 pandemic is a global health emergency with a real or potential impact on populations worldwide (1).

COVID-19 spreads mainly via contact with an infected person through droplets whenever they sneeze or cough. If a person comes in contact with some virus-contaminated surface and then touches his mouth, eyes, or nose, can infect itself with this disease (2). Few other names were given to COVID-19 were:- Novel Coronavirus Pneumonia, nCoV-2019 Acute respiratory disease (3), Wuhan Coronavirus, Wuhan Pneumonia, and SARS-CoV-2 (4).

In such challenging times, different systems of medicine have proposed many possible ways to combat this disease, and one such approach is proposed by the Unani system of medicine. Unani Medicine is a widely practiced system of medicine in many parts of the world, specifically in India. It provides a detailed explanation of many drugs including drugs that are used in respiratory infections (5). And such wonderful drugs even possess precise antiviral activity in plentiful scientific studies (6). The most adept modes of health drive in Unani medicine is via improving Tabiyat (Medicatrix Naturae or Immunity) through immunomodulators, keeping balance in quantity and quality of humors, by striving to keep the balance of temperament, adoption of Ilaj Bil Tadabeer (Regimental therapy) and through restraint of Asbab-e-Sitta Zarooriya (six essential factors for life) $(7,8)$.

\section{COVID-19}

\section{SARS CoV-2}

Coronaviruses belong to the Coronaviridae family and appear just like spiked rings when seen through an electron microscope. It spells and muddles living cells with the help of numerous spikes on its surface. Coronaviruses are the viruses causing the simple common cold diseases to severe diseases like Middle East Respiratory Syndrome (MERS$\mathrm{CoV}$ ), and Severe Acute Respiratory Syndrome (SARS-CoV). This virus does not remain viable after 4 hours on copper, 24 hours on cardboard, 72 hours on stainless steel \& plastic. The 
virus has also been found in feces up to the duration of 1 to 12 days, and transmission via feces is being explored (9).

These coronaviruses possess a positive-sense singlestranded RNA genome (27 to 34 kilobases) and helical symmetry nucleocapsid. Characteristically, the coronaviruses are of $\sim 20 \mathrm{~nm}$ size draped with a hefty petal or club-shaped surface appearance (10). It is now revealed that SARS-CoV-2 has a $96.2 \%$ structural resemblance with a bat coronavirus (CoV RaTG13) and 79.5\% correspondence with SARS-CoV. Though, its spike (S) glycoprotein has a 10-20 times greater affinity to human ACE2 receptors as likened to SARS-CoV, leading to more chances of human-to-human transmission; However, it has a lesser mortality rate (average 3.4\%) than that of SARS (9.6\%) and MERS (35\%) respectively (11).
- Difference between SARS CoV-2, MERS-CoV, and SARS-CoV

SARS-CoV in 2003, was originated in southern China and transmitted to Hong Kong and 29 other countries with high human morbidity, leading to 8098 confirmed cases and 774 deaths (12). In 2012, MERS emerged as a worldwide death trial in countries close to the Arabian Peninsula. As of July 31, 2019, a total of 2458 confirmed MERS cases, and 848 deaths were found, approximately $80 \%$ of these cases have been reported only in Saudi Arabia (13). The progression of infection was found to be rapid with MERS-CoV as compared to SARS-CoV, and the reported mortality rates were $34 \%$ and $10 \%$, respectively (14) (15). The difference between MERS$\mathrm{CoV}$, SARS-CoV, and SARS CoV-2 has been mentioned in the table given below.

Table 1-Epidemiological difference between SARS CoV-2, MERS-CoV, and SARS-CoV.

\begin{tabular}{|c|c|c|c|}
\hline Characteristics & SARS CoV-2 & MERS-CoV & SARS-CoV \\
\hline Genus & Beta-CoVs, lineage $B$ & Beta-CoVs, lineage C & Beta-CoVs, lineage B \\
\hline Intermediary Host & Malayan pangolins & Dromedary camel & Palm civet \\
\hline Symptoms & $\begin{array}{l}\text { Fever } \\
\text { Cough } \\
\text { Shortness of } \\
\text { Breath } \\
\text { Fatigue }\end{array}$ & $\begin{array}{l}\text { Fever } \\
\text { Chills } \\
\text { Diarrhea } \\
\text { Nausea } \\
\text { Vomiting } \\
\text { Congestion } \\
\text { Sneezing } \\
\text { Sore throat }\end{array}$ & $\begin{array}{l}\text { Fever } \\
\text { Dry Cough } \\
\text { Headache } \\
\text { Difficulty in } \\
\text { breathing } \\
\text { Muscle aches } \\
\text { Loss of appetite } \\
\text { Diarrhea }\end{array}$ \\
\hline Natural Reservoir & Bat & Bat & Bat \\
\hline Origin & Wuhan City, Hubei Province of China & Guangdong Province & Arabian Peninsula \\
\hline Confirmed Cases & $68,165,877$ (December, $\left.10^{\text {th }}, 2020\right)$ & 2458 (July 31st, 2019) & 8098 \\
\hline Total deaths & $1,557,385$ (December, $\left.10^{\text {th }}, 2020\right)$ & 848 & 774 \\
\hline $\begin{array}{l}\text { Transmission } \\
\text { Pattern }\end{array}$ & $\begin{array}{l}\text { From animal to human; } \\
\text { from human to human }\end{array}$ & $\begin{array}{l}\text { From animal to human; } \\
\text { from human to human }\end{array}$ & $\begin{array}{l}\text { From animal to human; } \\
\text { from human to human }\end{array}$ \\
\hline Recovery & 2-8 weeks & 6-7 weeks & 5-6 weeks \\
\hline $\begin{array}{l}\text { Complications if } \\
\text { any }\end{array}$ & $\begin{array}{l}\text { Acute pneumonia, septic shock, } \\
\text { Respiratory failure in adverse } \\
\text { conditions. }\end{array}$ & $\begin{array}{l}\text { Acute pneumonia and kidney } \\
\text { failure in adverse conditions }\end{array}$ & $\begin{array}{l}\text { Heart, Liver and } \\
\text { Respiratory failure in } \\
\text { adverse condition. }\end{array}$ \\
\hline Treatment if any & $\begin{array}{l}\text { No vaccines available, only } \\
\text { Symptoms can be treated. } \\
\text { A lot of drugs are under trial. }\end{array}$ & $\begin{array}{l}\text { Treatment only for symptoms } \\
\text { such as Fluids replacement } \\
\text { Oxygen therapy. }\end{array}$ & $\begin{array}{l}\text { Breathing ventilator to } \\
\text { deliver Oxygen. } \\
\text { Pneumonia treating } \\
\text { antibiotics } \\
\text { Antiviral medicines } \\
\text { Steroids to reduce lung } \\
\text { swelling }\end{array}$ \\
\hline
\end{tabular}




\section{Symptoms}

Common symptoms include fever, dry cough, and fatigue. Uncommon symptoms such as shortness of breath, pain in muscles or joints, loss of smell, headache, sore throat, diarrhea, nausea, or vomiting. In serious cases symptoms like confusion, bluish face, coughing up blood, chest pain, decreased RBC, High fever and multi-organ failure can be observed (16) (17) (18).

\section{Pathogenesis}

The main pathogenesis of SARS CoV-2 infection as a respiratory system attacking the virus was severe pneumonia, which was observed with ground-glass opacities along with acute cardiac injury witnessed in some cases. Raised levels of cytokines and chemokines in blood were found in patients with SARS CoV-2 infection that included IL1- $\beta$, IL1RA, IL7, IL8, IL9, IL10, basic FGF2, GCSF, GMCSF, IFN $\gamma$, IP10, MCP1, MIP1 $\alpha$, MIP1 $\beta$, PDGFB, TNF $\alpha$, and VEGFA. (19).

\section{Diagnosis}

- CDC RT-PCR: (Polymerase chain reaction) test Kit for Covid-19 (20)

○ X-ray Chest

- CT-Scan of the chest

\section{Vaccine for Coronaviruses}

Recently, many groups are working hard to design a vaccine using a variety of platforms against CoVs. Few of these methods have revealed effectiveness in animal models. The spike (S) protein present in CoVs acts as a viral antigen and in control of host-receptor binding and virus internalization and induces robust humoral and cell-mediated responses in humans when they are possessing infection. The $S$ glycoprotein has been revealed to have a role in the internalization of other CoVs like SARS by binding to its cellular receptor angiotensin-converting enzyme 2 (ACE2). The $S$-protein plays a role in receptor binding and membrane fusion makes it the perfect target for the creation of vaccines against CoVs (21).

\section{Treatment}

Various controlling strategies are taken into consideration like lessening the secondary infections by prompt diagnosis and isolation of cases, providing optimum health care facility to infected individuals, and the development of operative diagnostic, therapeutic and preventive approaches, including vaccines. A combination of azithromycin and hydroxychloroquine is effective in some cases. In serious cases, the use of passive antibodies, selective cytokine blockade, and some steroids are projected. Antivirals such as lopinavir/ritonavir, ribavirin, etc. are also in use as a provisional treatment choice for Covid-19 (22). There are no specific antiviral drugs or vaccines verified to be completely effective or a cure against SARS-CoV-2, hence the stress is being laid on prevention and symptomatic management (23).

The Unani system of medicine focuses on prevention via dietary management, lifestyle alteration, prophylactic interventions for enhancement of immunity, and simple remedies as per the presentations of the symptoms (24). For preventive and prophylactic purposes Ministry of AYUSH has recommended a decoction which should be prepared by boiling, Behidana (Cydonia oblonga) 3gm, Unnab (Zizyphus jujuba) 5 in number, Sapistan (Cordia myxa) 9 in number in $250 \mathrm{ml}$ water, decoction should be consumed when it is lukewarm. The drugs used in the preparation of this ISSN: 2250-1177 decoction possess antioxidant, immunomodulatory, antiallergic, smooth muscle relaxant, and anti-influenza properties. This decoction may be taken twice a day for 14 days (24). Few compound formulations are also advised like Khamira Marwareed 3-5gm once a day, Tiryaq Arba 3-5gm twice a day, Tiryaq Nazla 5gm twice a day, Sharbat Unnab 10-20 ml twice a day, Arq Ajeeb 4-8 drops in freshwater four times a day. (24) (25).

Role of six essential factors for life (Asbab-eSitta Zarooriya) in times of Pandemic COVID19

According to the Unani system of medicine "Asbab" are the factors which are originators and have an effect on the human body to generate a new state or to maintain an old state. Asbab-e- Sitta Zarooriya are known as six essential factors of life without them the life of humans is unimaginable and they are amongst the important regimens for health preservation. When all the six factors are in equipoise, health is maintained; otherwise, it needs moderation and modification. The effects of each factor on human health are as follows:

\section{Fresh Air (Hawae Muheet):}

Great importance is given to clean air in Unani medicine as clean and good air is essential for good health; many diseases occur due to variations in the air. Ibn Sina, a renowned Unani scholar described in his famous treatise, Canon of medicine, that the change of environment relieves the patients of several ailments. He has also highlighted the need for open airy houses with proper ventilation, play-grounds, and gardens in cities so that everyone has adequate fresh air and a proper ecological balance is upheld (26). The basic major advice is to evade places where an epidemic is spread. In case it is not preventable, then an individual is advised to stay at a well-ventilated place, preferably distant from the ground. When intermingling with a patient, care must be taken that the air currents may not be directed from a patient to a healthy individual (27).

Waba (epidemic) is understood as an alteration in the 'jauhar' (essence) of air. As a result, the air becomes contaminated and finally, it leads to the mal temperament of ruh which becomes responsible for mortality or morbidity of a big number of individuals. This situation perseveres until the air turn pure (28). Hippocrates, the father of epidemiology, was the first person who described the importance of air, its quality and characteristics in respect of health and disease as well as endemics and epidemics due to air pollution and wrote a book titled "Air, Water, and Places". The book "Air, Water, and places" is a breakthrough in preventive and social medicine and every epidemiologist refers to him (29).

\section{Food and Drink (Makool Mashroob):}

Here the word makool is used for foods and mashroob for drinks (28). It is advised that the food that we eat should be fresh, free from decay and disease-producing substances and drinking water should also be pure (26). Avicenna stated in his famous treatise "Alqanun" that Dietetics and Nutrition is one of the significant medical subjects and Avicenna further alleged that, "the stomach is the house of disease and the diet is the head of healing". Unani physicians used to treat patients with the help of a regimen starting with physiotherapy and diet; if this failed, then drugs have opted as Rhazes stated "if the physician can treat with foodstuffs, not medication, then he has succeeded. Unani physicians recommended diet plans according to ages, for instance, for Infant's diet, Galen suggested that mother milk is the 
paramount food; which must be given to the baby before the teething process after light and liquid diet can be given. Young adults require food three times a day with proper digestion. Galen affirmed that elderly people should take food as per their Mizaj (temperament). It is further advised that a person should refrain from a meal on a full stomach (29). Food such as meat-soup prepared with Roman wheat and barley is beneficial for the elderly (30).

Throughout epidemics, it is directed to avoid meat, sweets, and fruits with high water content (31). It is also recommended to eat citrus and sour fruits, especially grapes, apples, lemon, oranges, etc. Oxymel prepared with Arq-eGulab is thought to provide active protection during epidemics $(27,32)$. Overeating and under-eating both are considered damaging as they have adverse effects on the bodily constitution and unnecessarily remaining thirsty was also known to be harmful (33).

\section{Body Movement and Repose (Harkat wa Sukoone Badani):}

To uphold faultless health and a good physique, the body needs exercise as well as rest (26). A great Unani Scholar Avicena said; "By doing appropriate exercise at a suitable time; one can remain healthy and refrain himself from diseases". Avicena also said that "Exercise is the source of worthy health if done in satisfactory quantity at the accurate time". Physical activity aids many parts of the body like the heart, skeletal muscles, bones, blood, immune system, and nervous system while lack of physical activity works as a risk factor for many diseases such as heart attack, anxiety, hypertension, depression, type 2 diabetes, and obesity, etc. (29). According to Razi (865-925 CE), people who keep themselves physically active with regular exercises routine have a reduced vulnerability to epidemic diseases (34). People with weak immunity and those suffering from underlying illnesses are said to be more prone to acquire the infection during epidemics (33).

\section{Mental Movement and Repose (Harkat wa Sukoone Nafsania):}

Emotional issues such as anger, happiness, fear, sorrow, etc. have a substantial effect on the well-being of an individual. Unani physicians believe that some specific diseases like mental disorders and hysteria are caused in most cases by emotional disturbance and strain and therefore while treating such patients, a physician must consider all such factors. A specific division of Unani medicine known as Illaj Nafsania (Psychological treatment) deals with psychological issues and numerous ailments are treated with psychological means, sometimes this sort of management cures the ailment without using medicines and at times by using medicines along with psychological methods (26).

In the current scenario complaints of the feeling of depression is high among people during the COVID 19 pandemic and it was significantly more in illiterate, unskilled workers and who belong to lower socioeconomic class for which many reasons could be cited like homesickness, unemployment, a sudden change in lifestyle, etc. (35). The emotional state of a person has a significant role in the maintenance of health because the negative emotions make a person physically unwell and positive emotions boost the immune system. Therefore, balance with emotions, psychic rest, and movement is indispensable for the safeguarding of existing health or to restore health, if it is lost (28).

\section{Sleep and Wakefulness(Naum wa Yaqzah):}

For a healthy individual, it is very much required to maintain the normal pattern of sleep and wakefulness. Sleep can be considered as an ideal form of rest, mental as well as physical. Inadequate sleep causes digestive troubles, mental weakness, and loss of energies (26). A renowned Unani scholar Zakariya Razi suggests that eight hours of sleep is very important for optimum health. He also said that sleep fortifies the vital faculty, pneuma, and maintains a healthy digestive process. Excessive sleep causes dullness of the psychic faculties, cold diseases, and a feeling of heaviness of the head while excessive wakefulness produces dryness and impairs digestion (28). The normal physical and psychosocial functions depend on a sufficient amount of sleep. A wellknown Unani scholar Ibn Nafis explained the important role of wakefulness and stated that all the voluntary movements and functions of the body occur in a wakeful state but an excess of awakening produces dissolution of Ruh (Pneuma) leads to indigestion and weakness and dryness qof brain (29). A balanced sleeping pattern is essential to sustain a healthy life.

\section{Ehtibas wa Istafraagh (Retention and Evacuation):}

Ehtebas means the retention of essential nutrients, minerals, electrolytes, and water in the body where Istefragh signifies the evacuation of morbid materials to clean the body. Ehtebas-wa-Istefragh is categorized into two categories, the normal and abnormal ones. Normal (Tabaie) Ehtebas helps in retaining the makul-wa-mashrub for proper digestion and metabolism after that Tabiyat retains certain useful endproducts of metabolism for Numu-wa-Tauleed (Growth and Reproduction) e.g. normal retention of salts, vitamins, fats, proteins, electrolytes, and minerals, etc (29). The normal paths of excretion are defecation, diuresis, excretion via uterus in the form of menses, diaphoresis, vomiting, via ears, nose, eyes, and respiration. The appropriate and normal excretory function must be safeguarded to maintain optimum health. Any trouble in the normal excretory balances, whether it be blockage, excess, or diminution results in the occurrence of disease. Physicians of the Unani system of medicine since time immemorial treated several ailments via regulating the excretory processes (26). But anomalous Istefragh of any matter always causes the dryness and coldness of temperament directly and weakens the Tabiyat e.g. excess loss of nutrients, salts, and fluid in the stools, causes dehydration, and it may prove fatal if not managed timely and with proper care. A common example of abnormal ehtebas is acute or chronic constipation while diarrhea is a common example of abnormal Istefragh. Consequently, if retention and evacuation are balanced and occur through proper channels at the correct time, then they are proved beneficial in regulating health, otherwise, imbalance of both can be very harmful (29). 


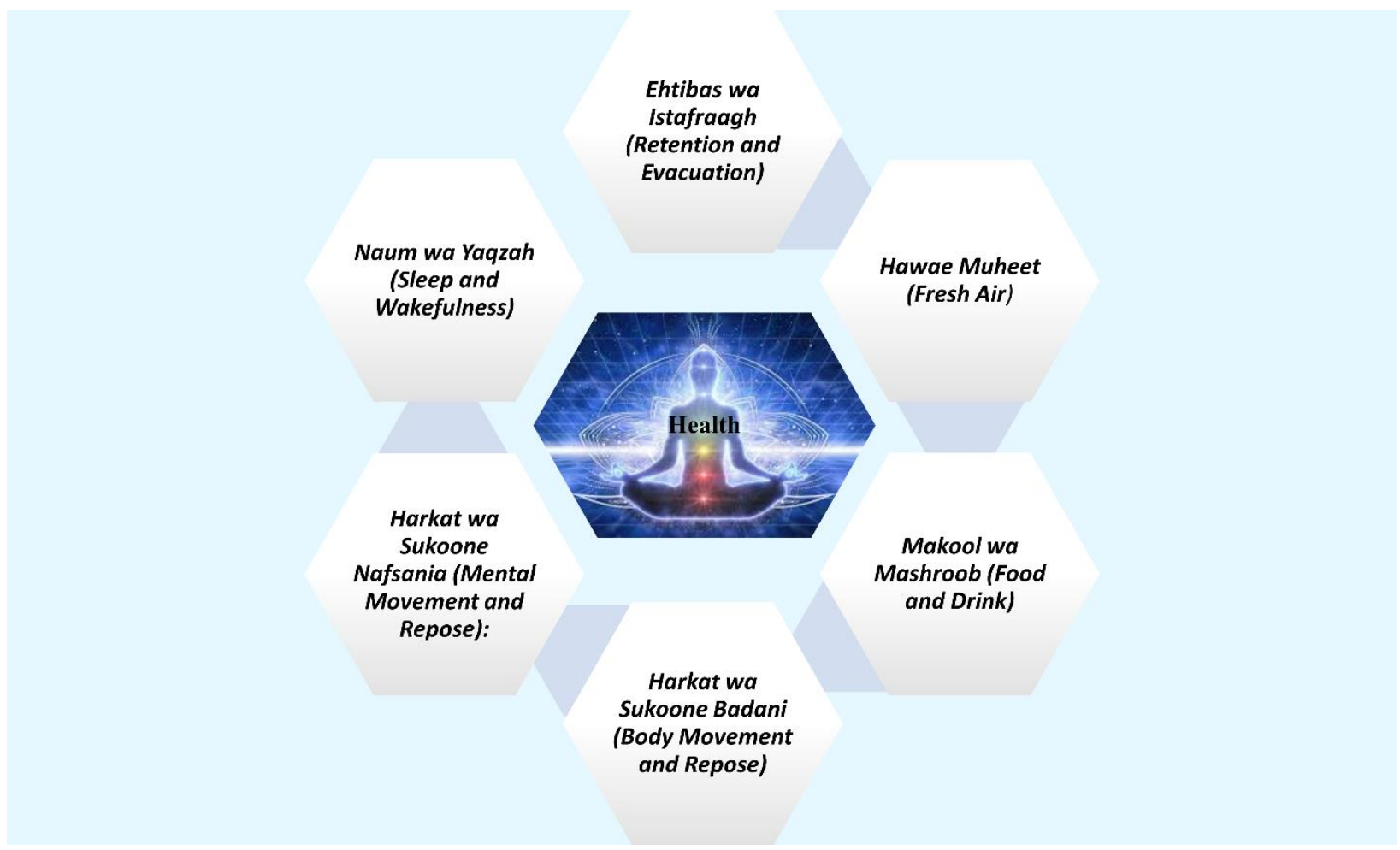

Figure 1: Asbab-e-Sitta Zarooriya (Six essential factors for life).

\section{Preventive measures}

Personal hygiene, improvement of immunity, an adaptation of anti-septic measures, inhibition of the spread of infection, and promotion of general health are some of the important measures people need to take this time. Host defenses should be given specific importance (31). Maintain optimum personal hygiene, avoid touching nose, eyes, and mouth with grubby hands, wash hands with antiseptic soap, avoid unnecessary traveling, avoid consumption of raw/ undercooked meats, wear a mask specifically when you have a sore throat, cough, runny nose (36). Guidelines for isolation, quarantine, and social distancing must be followed accurately.

\section{Conclusion}

As the world is going through a major health crisis, there is a dire need to dig out the hidden treasure of knowledge from this olden medicine system. One can easily stay safe from many diseases if one strives to keep a balance among Asbabe-Sitta Zarooriya (six essential factors for life). However, there is a possibility that such epidemics will occur in the future, maybe with the arrival of more violent and challenging organisms, in this context, there is a need to develop new infection control methods that are reachable to the entire population of the world. In the nonexistence of any effective treatment choices available for Covid-19, stress is being given on traditional systems of medicine to provide the essential shield against such diseases. India has been reassuring the application of science and technology in AYUSH systems through policies and development of ISM pharmacopeia is an on-going determination on this path. However, much more is required and the trials raised by the COVID-19 pandemic permit modernizing the systems with the help of novelties efficiently using science and technology. Also, there is a necessity to teach our new generations the importance of science and technology to combat such disaster in the future.

\section{Funding}

None.

\section{Declaration of competing interest}

The authors declare that they have no known competing financial interests or personal relations that could have seemed to affect the work reported in this paper.

\section{Acknowledgments}

None.

\section{References}

1. Romanov BK. Coronavirus disease COVID-2019. Safety and Risk of Pharmacotherapy. 2020; 8(1): p. 3-8.

2. WHO. Naming the coronavirus disease (COVID-19) and the virus that causes it. ; on 28.2.2020.

3. en.nhc.gov.cn. A daily briefing on novel coronavirus cases in China. ; 7 Feb 2020

4. Campbell C. "The Wuhan Pneumonia crisis highlights the danger in china's opaque way of doing things". ; time retrieved 13 march 2020.

5. Vohora SB. Unani Joshandah Drugs for Common Cold, Catarrh, Cough, and Associated Fevers. Journal of Ethnopharmacology. 1986; 16(2-3): p. 201-202.

6. Cagno Vea. Ficus Religiosa L. Bark Extracts Inhibit Human Rhinovirus and Respiratory Syncytial Virus Infection in Vitro. Journal of Ethnopharmacology. 2015; 176: p. 252-5.

7. Kabiruddin A. Tarjuma wa shrah Kulliyate Qanoon Delhi: Idara Kitab Ush Shifa; 1999.

8. Kabiruddin A. Tarjuma wa Shrah Kulliyate Nafisi Delhi: Idara Kitab Ush Shifa; 2009.

9. Water transmission and Covid-19. ; Accessed, 19 March 2020

10. Ali I, Alharbi ML. COVID-19: Disease, Management, Treatment, and Social Impact. Science of the Total Environment. 2020; 728: p. 138861.

11. Guo YR, Hong ZS. The origin, transmission, and clinical therapies on coronavirus disease 2019 (COVID-19) outbreak- An update on the status. Military Medical Research. Military Medical Research. 2020; 7(1): p. 1-10.

12. Hui SC, Zumla. Severe Acute Respiratory Syndrome: Historical, 
Epidemiologic, and Clinical Features. Infectious Disease Clinics of North America. Elsevier Inc. 2019; 34(4): p. 869-889.

13. Zheng Jea. Middle East respiratory syndrome coronavirus seropositivity in camel handlers and their families, Pakistan. Emerging Infectious Diseases. 2019; 25(12): p. 2307-2309. DOI: 10.3201/eid2512.191169.

14. Chen Nea. Epidemiological and clinical characteristics of 99 cases of 2019 novel coronavirus pneumonia in Wuhan, China: a descriptive study' 395(10223). The Lancet. Elsevier Ltd. 2020; 395(10223): p. 507-513.

15. Sonja A. Rasmussen AKWDLS. Middle East Respiratory Syndrome (MERS) Washington DC: ASM Press; 2016.

16. WHO. Q\&A on coronaviruses (COVID-19). ; 11 March 2020.

17. WHO. Q\&A on coronaviruses (COVID-19). ; 2020.

18. Cao , Li T, Liang L. Clinical characteristics of Coronavirus Disease 2019 patients in Beijing, China. PLOS ONE.

19. Huang C, Wang Y, Li X, al. e. Clinical features of patients. Lancet. 2020; 395(10223): p. 497-506.

20. F. CDC test for 2019-nCoV. Archived from the original on $14 \mathrm{Feb}$ 2020.

21. Wang Qea. MERS-CoV spike protein: Targets for vaccines and therapeutics. Antiviral Research. Elsevier B.V. 2016; 133: p. 165177.

22. Nikhat S, Fazil M. Overview of Covid-19; its prevention and management in the light of Unani medicine. Science of the Total Environment. Elsevier B.V. 2020; 728: p. 138859.
23. Jean SS, Lee PI, Hsuehd PR. Treatment options for COVID-19: The reality and challenges. Journal of Microbiology, Immunology and Infection. Elsevier Taiwan LLC. 2020; 53(3): p. 436-443.

24. AYUSH D. Government of Uttar Pradesh, Covid-19, Paramarsh..

25. Advisory for Corona virus, Unani medicine useful in symptomatic management of corona virus. ; 2020.

26. LONE A, AHMAD , ANWAR , SOFI , IMAM. Perception of health promotion in Unani herbal medicine. J ournal of Herbal Medicine. Elsevier GmbH. (no date); 2(1): p. 1-5.

27. Razi Z. Kitab Al-Mansoor New Delhi: Central Council for Research in Unani Medicine. Ministry of Health and Family Welfare; 1991.

28. Nasiruddin, Zulkifle, Khan. Asbab-e-Sitta Zaruriyya ( six essential factors ): An Unique tool for the maintenance of human health. 2015; 3(4): p. 22-24.

29. Alig FA. Six essential factors and health. 2019; 3(1): p. 29-36.

30. Nigar Z. Unani Concept of Prevention and Control of Lifestyle Disorders: A Literature Unani Concept of Prevention and Control of Lifestyle Disorders : A Literature Review. 2020 May.

31. Rushd I. Kitab al-kulliyat: Urdu Trans; 1987.

32. Rushid. Kitab ul Kulliyat Delhi: CCRUM; 1987.

33. Sina I. Al qanoon fil tib Lucknow: Munshi Nawal Kishore; 1878.

34. Razi Z. Kitab al Hawi New Delhi: CCRUM; 2008.

35. H, Nazli , Grover , Kishore. Covid 19 Pandemic and "Feeling Depressed ": An Online Survey. 2020; 5(2): p. 27-31.

36. Ayush Do. Government of Uttar Pradesh, Covid-19, Paramarsh. [Online]. 